\title{
UPAYA GURU PPKn DALAM MEMBENTUK MORALITAS SISWA
}

\author{
Ade Millatus'saadiyah ${ }^{1}$, Agung Setia Budi ${ }^{2}$ \\ Universitas Banten Jaya \\ Serang, Indonesia \\ Ade.millatus@gmail.com¹, Setiabudia322@gmail.com²
}

\begin{abstract}
This mini Thesis examines effort teacher education pancasila and civic in estabilishment of morality student of class VIII MTs Shiddiq Al Farizy Baros. This research was backround by the importance of estabilishment of moral student, because observe from deviance away from etnic and manner. Moral is foundation for implant to student for be generation who is a noble. Effort teacer education pancasila and civic in estabilishment of morality student of class VIII MTs Shidiq Al Farizy Baros thisi research descriptive, qualitative, namely data, obtained likr result observe, interview, observe, dokumentation. This reserch indicates that factors that because student of MTS Shiddiq Al Farizy Baros pembiasaan, keteladanan, discus, speech, simulation ass well ass reward and punishment. Resulf from this research indicated with change in attitude and behaviour of students toward better with reflect habit obey regulation teacher when learning in the class.
\end{abstract}

Keyword: Effort teacher education pancasila and civic, Morality Student. 


\section{PENDAHULUAN}

Pendidikan merupakan suatu proses terhadap anak didik berkangsung terus sampai anak didik mencapai pribadi dewasa susila (Hasbullah 2015:5). Proses ini berlangsung dalam jangka waktu tertentu.Bila anak didik sudah mencapai peribadi dewasa susila, maka ia sepenuhnya mamapu bertindak sendiri bagi kesejahteraan hidupnya dan masyarakatnya. Sesuai dengan Undang Undang No 20 Tahun 2003 tentang pendidikan nasional bahwa pendidikan adalah mengembangkan kemampuan dengan membentuk watak serta peradaban bangsa yang bernartabat dalam rangka mencerdaskan kehidupan bangsa, bertujuan untuk berkembangnya potensi peserta didik agar menjadi manusia yang beriman dan bertaqwa kepada tuhan yang maha esa, berakhlak mulia, sehat, berilmu, cakap, kreatif, mandiri dan menjadi warga negara yang demokratis serta bertanggung jawab. Pendidikan adalah usaha sadar dan terencana untuk mewujudkan suasana belajar dan proses pembelajaran agar peserta didik secara aktif mengembangkan potensi dirinya untuk memiliki kekuatan spiritual keagamaan, pengendalian diri, keperibadian, kecerdasan, akhlak mulia, serta keterampilan yang diperlukan dirinya, masyarakat, bangsa dan Negara. Salah satu hal yang peting dalam mewujudkan, pendidikan yang berkualitas salah satunya adalah guru (Hasbullah 2015:4) "Guru adalah salah satu komponen manusiawi dan proses belajar mengajar yang ikut berperan dalam usaha pembentukan sumber daya manusia yang potensial di bidang pembangunan (Moh. User Usman, 2002:17 dalam Amirudin 2013:3). Oleh karena itu, guru merupakan salah satu unsur di bidang kependidikan yang harus berperan aktif dalam menempatkan peranannya sebagai tenaga professional sesuai dengan tuntutan masyarakat yang semakin berkembang.

Dalam hal ini guru tidak semata-mata sebagai pengajar tetapi juga sebagai pendidik dan juga sekaligus pembimbing yang memberikan pengarahan dan menuntun siswa dalam belajar. Berkaitan dengan hal itu, guru memiliki peran yang sangat unik dan kompleks di dalam proses pembelajaran untuk mengantarkan peserta didik ke taraf yang dicita-citakan sesuai dengan profesi dan tanggung jawabnya.

Guru adalah pendidik profesional dalam tugas utama mendidik, mengajar, membimbing, melatih, mengarahkan, menilai dan mengevaluasi peserta didik pada pendidikan anak usia dini, pendidikan dasar, dan pendidikan menengah jalur pendidikan formal (UU No. 14 tahun 2005 tentang guru dan dosen) dalam (Supardi 2013:8). "Guru merupakan faktor penting 
yang besar pengaruhnya terhadap proses dan hasil belajar, bahkan sangat menentukan berhasil dan tidaknya peserta didik dalam belajar (Supardi 2015: 28)." Menanamkan nilai-nilai moral kepada siswa merupakan tanggung jawab semua guru di sekolah, hal ini perlu ditegaskan karena sering kali muncul anggapan yang paling berperan dan bertanggung jawab dalam menanamkan nilai-nilai moral pada siswa adalah guru Agama dan guru PPKn. Memang tidak dipungkiri bahwa mata pelajaran Agama dan PPKn banyak mengandung materi nilai-nilai moral, namun menyangkut penanaman nilai-nilai moral pada siswa tidak hanya dibebankan pada guru tertentu saja melainkan harus dilaksanakan oleh semua guru, sebab tanggung jawab menanamkan nilai-nilai moral merupakan tanggung jawab bersama, semua guru, keluarga, dan masyarakat dituntut menanamkan nilai-nilai moral kepada siswa. Konteks inilah sehingga pelajaran pendidikan pancasila dan kewarganegaraan sesungguhnya tidak berorientasi pada pemberitahuan pengetahuan semata melainkan berupaya pula memberikan penanaman nilai nilai moral. Hal ini sangat penting karena mata pelajaran PPKn berisikan materi yang diharapkan dapat menjadikan siswa lebih memiliki nilai dan moral yang tinggi. Oleh karena itu, suatu kegiatan belajar mengajar sangat bergantung kepada kemampuan guru dalam menyampaikan dan mengorganisasikan bahan pelajaran dan pengelolaan kelas. Keberhasilan proses belajar mengajar di kelas pada dasarnya merupakan keberhasilan belajar siswa yang didukung oleh keberhasilan mengajar guru.

Berdasarkan Hasil Peneliti pada tanggal 21 November 2017, menemukan bahwa Tingkat moral Siswa kelas VIII MTs Shiddiq Al Farizy Kecamatan Baros masih kurang baik diantaranya kurangnya sopan santun terhadap guru, sering berbicara kasar kepada guru, dan ini adalah salah satu faktor utama permasalahan Untuk mengatasi permasalahan tersebut diperlukan berbagai upaya untuk membentuk moralitas siswa, upaya tersebut yaitu guru PPKn harus berusaha agar siswa siswanya mempunyai sikap yang baik, kecerdasan yang tinggi serta keterampilan yang bermanfaat, oleh karena itu guru PPKn harus memanfaatkan sebagai fungsinya sebagai penuntun moral, sikap serta memberi dorongan kearah yang lebih baik (prima melati 2016:67). Selain guru, peran orang tua sangat penting dalam membentuk moral anaknya. Secara umum, dikenal bahwa yang memiliki disiplin yang tinggi di sekolah berasal dari orang tua yang demokratis dan otoriter, sedangkan siswa yang memiliki disiplin yang rendah dari orang tua yang permisif. Akan tetapi hal tersebut tidak selamanya benar karena ada juga beberapa siswa memiliki moral 
yang tinggi di sekolah, padahal ia berasal dari orang tua yang permisif serta ada pula beberapa siswa yang memiliki moral yang rendah padahal ia berasal dari orang tua otoriter dan demokratis. Peran guru dalam membentuk moral Siswa kelas VIII MTs Shiddiq Al Farizy Kecamatan Baros di harapkan mampu memahami keadaan jiwa peserta didiknya dan dapat membantunya dalam mengatasi berbagai masalah uraian diatas, berdasarkan latar belakang masalah, maka peneliti tertarik untuk mengkaji permasalahan tersebut dengan judul'Upaya

\section{Guru PPKn Dalam Membentuk} Moralitas Siswa kelas VIII MTs Shiddiq Al Farizy Kecamatan Baros."

\section{METODE PENELITIAN}

Tempat penelitian dilakukan di MTs Shiddiq Al Farizy Baros . Adapun untuk waktu penelitian nya itu sendiri dimulai dari tanggal 21 juni 2018. Subjek penelitian ini adalah Kepala sekolah dan 1 guru PPKn dan 13 siswa di MTs Shiddiq Al Farizy Baros.

Data yang terkait bisa diperoleh ketika proses pengumpulan data tersebut dipersiapkan dengan matang. Dalam penelitian ini akan digunakan beberapa cara untuk mengumpulkan data selama proses penelitian, diantaranya adalah Observasi, wawancara dan dokumentasi.

Observasi adalah teknik pengumpulan data dengan cara mengamati tingkah laku pada situasi tertentu (Arikunto, 2002 : 133). Metode observasi dapat dilakukan terhadap kelompok dan terhadap siswa secara individual. Kegiatan yang diamati adalah aktivitas guru dan siswa dalam mengikuti pembelajaran yang diamati dengan instrument.Observasi ini dilakukan di kelas VIII Mts Shiddiq Al- Farizy kecamatan baros. Peneliti melakukan observasi ini terhadap situasi pembelajaran dan mengamati tingkah laku siswa dan guru terhadap kegiatan belajar mengajar sehingga saya dapat meneliti kejadian yag dilakukan oleh guru dan siswa ketika kegiatan belajar mengajar berlangsung.

Wawancara atau Interviu (intervieuw) merupakan salah satu bentuk teknik pengumpulan data yang banyak digunakan dalam penelitian deskriptif kualitatif (PNana Saudih Sukmanidata 2015:216).Sedangkan menurut (Hasan 2002:85)Wawancara adalah teknik pengumpulan data dengan mengajukan pertanyaan langsung oleh pewawancara kepada responden, dan jawaban jawaban responeden dicatat atau direkam. Wawancara ini dilakukan kepada guru dan siswa mengenai upaya guru PPKn dalam membentuk moralitas siswa kelas VIII MTs Shiddiq Al Farizy Baros dalam ruang lingkup proses kegiatan belajar mengajar (KBM) yaitu jadwal saat belangsung kegiatan belajar mengajar (KBM). Wawancara ini dilakukan kepada siswa 
kelas VIII di MTs Shiddiq Al Farizy Baros dan juga kepada Guru Pendidikan Pancasila dan Kewarganegaraan. Dokumentasi adalah pengumpulan data berupa, gambar atau foto selama aktivitas penelitian berlangsung (Nana Saudih Sukmanidata 2015:221).

Dokumentasi adalah sebuah cara yang dilakukan untuk menyediakan berbagai macam dokumen, dengan menggunakan bukti yang akurat dari pencatatan sumber sumber informasi tersebut dapat berupa karangan atau tulisan, wasiat, buku, undang undang, ( Ahmad Suryan 2013:76). Dokumentasi diperlukan untuk melengkapi data yang diperoleh dari hasil observasi. Peneliti menggunakan dokumentasi yang ada diharapkan dapat memberikan gambaran dan penjelasan yang utuh sebagai pelengkap data yang diperoleh dari hasil penelitian.Dokumentasi ini berbentuk dokumen,lembar observasi,dan foto. Analisis data adalah proses mengatur urutan data, mengorganisasikannya kedalam suatu pola, kategori, dan satuan uraian dasar (Lexy Maleong 2002:103). Menurut bodgan dalam sugiono (2014:244) analsisis data adalah proses mencari dan menyusun secara sistematis data yang diperoleh dari hasil wawancara, catatan lapangan, dan bahan bahan lain sehingga dapat mudah dipahami, dan temuannya dapat diinformasikan kepada orang lain.

Berdasarkan kutipan diatas dapat disimpulkan bahwa teknik analisis data dalam penelitian ini terdiri dari beberapa langkah penelitian yang harus dilakukan untuk dapat melakukan analisis terhadap data yang ditemukan dilapangan.

Langkah langkah analisis data tersebut adalah (1) mencatat data lapangan, (2) Mengorganisasi data (3) Memilih milih data yang telah ditentukan (4) Mereduksi data yang tidak berkaitan dengan tujuan penelitian (5) Mensintesiskan data sehingga mudah dipahami (6) Mencari dan menentukan pola dan hubungan hubungan sesuai dengan tujuan peneliti (7) Membuat temuan umum peneliti

\section{HASIL PENELITIAN DAN PEMBAHASAN}

1. Upaya guru PPKn dalam membentuk moralitas siswa kelas VIII MTs Shiddiq Al Farizy Baros Guru PPKn dalam membentuk moralitas siswa harus berusaha agar siswa siswa nya mempunyai sikap yang baik, kecerdasan yang tinggi serta keterampilan yang bermanfaat, oleh karena itu guru PPKn harus memanfaatkan sebagai fungsinya sebagai penuntun moral, sikap serta dorongan kearah yang lebih baik (prima melati 2016:67)

Pada hasil observasi peneliti pelaksanaan pembelajaran dibagi ke dalam satu bagian yaitu (kelas VIII) Berdasarkan hasil observasi diperoleh hasil bahwa 
langkah-langkah pembelajaran dalam implementasi pendidikan moral melalui PPKn di kelas VIII sebagai berikut:

Kegiatan awal guru menanamkan sikap religius, sopan, dan berfikir logis. Langkah-langkah pada kegiatan pendahuluan guru menanamkan sikap sopan dengan mengucapkan salam dengan bersenyum kepada peserta didik saat memasuki ruang kelas yang dibalas dengan salam dari siswa. Guru menanamkan sikap religius dengan menyuruh siswa untuk berdoa. Kegiatan pendahuluaan guru menanamkan sikap santun dan religius seperti pada pertemuan pertama. Langkah- langkah yang dilakukan adalah mengucapkan salam dan memimpin doa. Selanjutnya bertanya kepada siswa. Kegiatan pendahuluan guru menanamkan sikap santun dan religius seperti pada pertemuan pertama dan kedua. Langkah-langkah yang dilakukan adalah mengucapkan salam dan memimpin doa. Selanjutnya guru menanamkan sikap logis dengan guru menanyakan kembali tadi apa saja yang harus kita lakukan agar dapat dihargai orang lain. Siswa menjawab berkata sopan, santun pada orang lain, mempunyai cita-cita yang tinggi. Selanjutnya guru melakukan post test.

Berdasarkan paparan diatas dapat disimpulkan bahwa guru sudah berusaha menanamkan nilai-nilai moral. Pada kegiatan awa yang ditanamkan antara lain sopan, religius dan berfikir logis. Banyaknya permasalahan di atas disebabkan oleh beberapa faktor diantaranya kemampuan guru yang belum menerapkan model pembelajaran yang dianggap tepat serta pembelajaran pendidikan moral yang masih kurang efektif. Upaya yang harus dilakukan untuk membentuk moralitas siswa yang baik adalah dengan mengubah cara mengajar guru. Guru diharapkan untuk menggunakan metode pembelajaran yang dapat menuntut siswa agar aktif inovatif dan menyenangkan. Peneliti melakukan wawancara terhadap orang orang yang peneliti anggap mengetahui tentang upaya guru PPKn dalam membentuk moralitas siswa kelas VIII MTs Shiddiq al farizy baros. Adapaun yang menjadi subjek wawancara yaitu Guru PPkn, Kepala sekolah dan Siswa.

Berdasarkan wawancara peneliti secara langsung terhadap guru PPKn di MTs Shiddiq al farizy baros yaitu dengan proses perencanaan. Peneliti melakukan teknik wawancara untuk memperoleh data dari persiapan guru sebelum memulai pelajaran. Menurut Abdul Latif, S.Sos selaku kepala sekolah MTs Shiddiq Al farizy perencanaan dilakukan dengan cara mengkolaborasikan nilai nilai sikap dalam pembelajaran, dan menyiapkan pembelajran moral melalui PPKn pada proses perencananaan dengan 
mengolaborasikan nilai nilai sikap dalam skenario pembelajaran. Kemudian guru PPKn mengungkapkan tahap perencanaan yang dilaksanakan adalah masukan nilai nilai moral kedalam silabus dan RPP. Guru PPKn mencantumkan muatan muatan kegiatan muatan tersebut meliputi perilaku dan ucapan yang sesuai dengan nilai nilai moral dalam merencanakan pembelajaran perencanaan tersebut dilaksanakan dan disisipkan dengan memasukan nilai nilai yang ada dalam moral peserta didik kedalam silabus dan RPP. Berdasarkan hasil wawancara dapat diambil kesimpulan bahwa guru di MTs. Shidiq Al-Farizy dalam membentuk moralitas siswa adalah dengan menyiapkan silabus, dan bahan ajar, silabus dan RPP yang dibuatkan dengan memuatkan nilai nilai moral didalamnya.

Dalam hasil temuan penelitian dapat didiskripsikan bahwa Langkah langkah guru dalam melaksankan pembelajaran yaitu Peneliti melakukan teknik wawancara untuk memperoleh data pelaksanaan pada mata pelajaran PPKn. Imanudin S.Pd mengatakan bahwa:

Langkah langkah guru dalam melaksanakan pembelajaran meliputi pendahuluan, pembahasan, inti, dan penutup. Berdasarkan hasil wawancara diperoleh bahwa dalam RPP guru menggunakan langka langkah pembelajaran kedalam tiga bagian. Langkah langkah yang ditulis adalah kegiatan awal kegiatan inti dan kegiatan penutup. Upaya guru dalam membentuk moralitas siswa guru selalu memberikan contoh yang baik terhadap siswa dengan datang kesekolah tepat waktu dan guru disini selalu menanamkan nilai moral kepada siswa. Jika ada siswa yang terlambat masuk kelas maka guru akan memberikan sangsi dan tidak mempebolehkan masuk ketika proses pembelajaran berlangsung

2. Hambatan guru PPKn dalam membentuk moralitas siswa kelas VIII MTs Shiddiq Al Farizy Baros

Berdasarkan hasil observasi, wawancara, dan dokumentasi Hambatan guru PPKn dalam membentuk moralitas siswa Kurangnya kedisiplinan siswa pada saat pembelajaran dilaksanakan.Hambatan kedisiplinan yang ada pada proses pembentukan moral pada siswa MTs Shidiq Al Farizy Baros. Pada prinsipnya tidak secara keseluruhan dilakukan semua siswa, ketidak disiplinan yang terjadi hanya dilkukan oleh beberapa siswa pada dasarnya. Berdasarkan hasil observasi peneliti, bahwa hambatan guru PPKn dalam membentuk moralitas siswa kelas VIII MTs Shiddiq AL Farizy Baros kurangnya ketegasan dalam menanamkan kedisiplinan ketika proses belajar mengajar, sehingga siswa tidak akan mengalami serius dalam belajar. Berdasarkan hasil wawancara peneliti, bahwa hambatan guru PPKn dalam 
membentuk moralitas siswa kelas VIII MTs

Shiddiq AL Farizy Baros kurangnya keberanian dalam mengambil langkah pembentukan moral siswa sehingga siswa tak terlalu serius ketika di berikan penjelasan.

\section{KESIMPULAN}

Pembelajaran yaitu guru mentiapkan alat bantu dalam pembelajaran seperti laptop infokus, buku, gambar bertujuan intuk mempermudah dalam belajar mengajar. Dengan membuat aturan yaitu guru membuat suatu aturan yang harus dipatuhi dan akan diberikan konsekuensi jika siswa melanggarnya. ke lima Memberikan motivasi guru memberikan motivasi kepada siswa mengenai tingkah laku yang baik yang harus dilakukan saat berinteraksi dengan orang lain. Yang ke enam Memberikan contoh yang baik yaitu seorang guru memberikan contoh sikap yang baik sehingga disimpulkan bahwa : Upaya Guru PPKn dalam Membentuk Moralitas Siswa Kelas VII Mts Shiddiq Al Farizy Kecamatan Baros Pertama Kegiatan pembelajaran, guru melakukan kegiatan pembelajaran dengan perencanaan implementasi pendidikan moral dengan menyiapkan silabus dan bahan ajar RPP yang memuatkan nilai nilai moral dilamnya.ke dua Penggunaan metode variatif yaitu guru melakukan metode ceramah dengan cara menjelaskan materi secara verbal dan dapat dimengerti oleh peserta didik, Penggunaan Media

membentuk moralitas siswa

\section{DAFTAR PUSTAKA}

Buku:

Hamalik, Oemar.2001 Proses belajar mengajar. Bumi Aksara. Jakarta.

Hasbullah. (2015). Dasar dasar imu pendidikan. Depok:PT Rajagrafindo Persada.

Mursidin. (2011). Moral sumber pendidikan. Bogor: Ghalia Indonesia.

Rozak, A. (2011). pengembangan profesi guru. jakarta: FITK UIN JAKARTA. solihatin, E. (2014). Strategi pembelajaran pkn. jakarta: PT.Bumi aksara.

Sukmadinata, N. S. (2015). Metode Penelitian Pendidikan. Bandung: PT Remaja Rosdakarya.

Wuryan, S. (2015). Ilmu Kewarganegaraan (civics). Bandung: Laboratorium Pendidikan Kwarganegaraan.

Zuriah, N. (2011). Pendidikan Moral dan Budi pekerti. jakarta: PT.Bumi Aksara 